\title{
A Teacher's Reflection on Effective Learning in Early Childhood
}

\author{
Insan Sheny Priyandita ${ }^{1 *}$ \\ ${ }^{1}$ Early Childhood Education, School of Postgraduate.Universitas Pendidikan Indonesia, Bandung, Indonesia. \\ *Corresponding author.Email: insansheny25@upi.edu
}

\begin{abstract}
Effective learning programs provided by teachers to children are the main foundation in achieving maximum children's skills. However, many educators have limited theoretical understanding about effective learning. Based on literature research this paper highlights the extent to which teachers understand effective learning in early childhood and illuminate the complexities of teacher's understanding about effective learning, especially for early childhood.
\end{abstract}

Keywords: Teacher, effective learning, early childhood, experts.

\section{INTRODUCTION}

Learning is the most important part in the activity process in providing stimulus to children so that they develop in their age stages. Learning activities are an activity that can produce abilities and skills in children [1]. The role of educators is very important in contributing to this stimulus. Teacher innovation and professionalism are among the aspects that greatly contribute to increasing the ability of teachers to provide stimulus to children [2]. This professionalism can be obtained through several wrong processes to improve skills by gaining knowledge in educating early childhood according to the stages. This knowledge can be obtained through the academic process of universities, training or workshops, as well as reading academic reference sources.

The process of developing knowledge can be done anywhere and anytime. Through this process, educators can gain a lot of knowledge and skills in analysing knowledge. Analysis of a knowledge must be practiced and learned continuously by adding as much knowledge as possible. Through these knowledge basics, educators are able to think critically about the development of current knowledge and make effective learning for children [2]. There are two kinds of effective learning, namely the quality of learning (Quality of instruction) and active learning time [3].

The level of achievement of learning objectives by students is one aspect of determining the effectiveness of learning carried out by educators. In addition, effective children's learning can be seen from the activities carried out by children, how students are involved, and the process to achieve the expected success [2]. This process can be seen from the learning interactions carried out by teachers with students, students with students and students with learning resources. This is what causes the effectiveness of learning to be closely related to the quality of learning, because the quality of the results of the learning process depends on the effectiveness of learning carried out by educators.

Therefore, to obtain effective learning knowledge to stimulate or stimulate children's development appropriately, educators are required to always think critically and understand the theories of experts about an understanding and knowledge that is provided as a basis for the process of learning activities at the child's educational level. early age. This article will look at the effectiveness of the learning process for early childhood based on 7 academic source theories.

\section{REFLECTION ON EXPERT VIEW}

It is very common that the national curriculum is the main reference for teachers in planning and conducting the learning activities and programs for the children. But the national curriculum may not be suitable for local circumstances or local context. Thus, teachers should be able to adjust the national curriculum to fit their schools' or societies' particularities.

Teachers need to understand theories in order to be able to adjust the national curriculum to the local context. Susan Kreig's paper entitled "To Teach or Not 
Teach in the Early Years: What Does this Mean in Early Childhood Education," provides a preliminary knowledge about four approaches to understand children's effective learning: child-centred learning, namely the constructionist approach, social constructionism, critical constructivism and cognitive constructivism.

First, constructivism believes that children build knowledge from their experiences [4]. Through this approach, it can be seen that the child's self is the key in developing knowledge. Activeness is an important thing in gaining experience so that knowledge in itself is more developed. On the contrary, social constructivism assumes that a child's knowledge is formed through social interactions with other people. So that through this approach it can be seen that an individual cannot stand alone, the social environment becomes an important aspect of his life. There is also a cognitive constructivism which believes that children's readiness in learning is innate. The cognitive constructivist approach sees children's learning focusing on the process of individual mental readiness. Through this approach, it can be seen that educators must provide learning programs according to age stages, so that the mental possessions of the children are ready to carry out the learning program.

This last section discusses a new approach based on the 3 approaches above. This approach is called a critical social constructionism approach which was born to provide a new perspective between child-centred and teacher-centred. This section combines child-centred learning with educator-centred learning. The function of this viewpoint is that with a combination of these approaches, children's development can be properly directed by teacher guidance but still with the needs and desires of the child.

The approaches above are explained by looking at the backgrounds generated through world history to see the real truth. According to MacNaughton, knowledge and truth used by several countries originated from western culture which is considered correct by minority countries [5]. Knowledge and truth can change according to the condition of society; therefore, educators and education observers are able to think critically to see the development of education in accordance with the needs of today's society. The truth that comes from power must be critically analyzed in order for it to suit the needs of today's society. Through this research, it can be seen that educators must have critical thinking in seeing the educational curriculum as a reference for developing learning programs used in early childhood education.

Educators must provide this critical analysis in order to be able to meet the needs and desires of today's society which are adjusted to technological developments.
The education provided must be tailored to the needs of today's society. History also shows that there has been a change in views on early childhood which has resulted in the development of education, especially early childhood education. This is explained in Burman's research which states that early childhood has a history of World War I, namely that children are made laborers [6]. Then after World War I, there were figures who fought for children's rights. From then on, children become someone who needs to be guided and cared for (innocent). This book shows that the sociocultural has begun to change from time to time. This also applies to the education sector, especially the education of age children, which starts from something that is not considered something that is important to be developed. Through this book, educators are also able to get information that educators need to pay attention to children's needs in providing learning programs so that children's development is in accordance with children's needs.

Through the times, the education system has begun to be adapted to the needs of children. The mindset began to be changed to become more modern. This is supported by Alloway's research which discusses postmodern views that can influence and change traditional beliefs about early childhood development practices [7]. The main principle of the postmodern view is to change absolutism into relativism, meaning that knowledge can be converted into truth by being transformed, redesigned and reshaped into knowledge or "truth" that is more complex and powerful. Through postmodern, educators are forced to leave comfort and certainty for the benefit of children. Through this journal, it can be seen that educators must have critical thinking skills in seeing the educational references set by the government in accordance with children's development or not. Through this critical thinking that is able to build further educational development. With this development of education, the learning programs provided by educators to children are appropriate to the child's needs. That is because these needs are not absolute but universalistic and can be changed according to current developments.

Educators and educational observers must make adjustments to the needs to produce a good education system. This adjustment can be made by looking at the needs of the community in various ways, including minorities. This is supported by research by MacNaughton which discusses the practice of freedom by seeing minorities as the basis for seeking fairer truths [8]. Through this book, it can be seen that educators must be critical in seeing the situation of minorities that cause injustice in education, especially early childhood education. This critical analysis can be done by seeking as much knowledge as possible either through academic sources or when in learning program activities. In addition, educators must also train themselves to 
overcome negative conditions by providing learning programs that are able to provide understanding for children to take positive actions.

Through the studies above, the learning program is continuously reviewed to see the suitability of conditions in society today. This was also done by the Indian state which saw the mismatch of learning programs that had references from Western culture. This is evidenced by research conducted by Gupta that the education system in India is heavily influenced by Western culture [5]. Meanwhile, the principles used by India are not in accordance with the principles of the Western cultural education system. The Western cultural system focuses more on individualistic child development, while the Indian culture views the education system as prioritizing togetherness or groups. This shows that educators must begin to be able to think critically to see the suitability between the educational references used and the reality in the field.

Apart from India, Korea is also a country that has a history of seeing the suitability of Western cultural education with their local culture. This is shown in Jahng's research which shows that Korean reconceptualization of kindergarten education is from a Western approach. According to Jahng the practice of education was universally dominated by Western economies and continued into the post-colonial period [9]. Western economic influences include the World Bank and UNESCO from America which established the education system in Korea by introducing Developmentally Appropriate Practices (DAP). This DAP is the practice guideline for early childhood education and the formation of national curricula in various countries using constructivist ideas from Piaget and Vygotsky.

India and Korea are among the countries that show the incompatibility of the Western education system with their local education. Research conducted by Mayo also shows that the education system can be implemented according to local needs. The research conducted by Mayo discusses the views of education and politics at the time of Gramsci. This research shows that Gramsi assesses that education is not only done by professional teachers, but can be done by anyone. In other words, according to Gramsci [10] education lies not only in formal education but also in non-formal and informal education. Through this journal it can be seen that children's education is not only carried out in schools with formal activities, but children can also study with other people in non-formal situations.

According to Jahng differences in the education system in the form of a global-based national curriculum led to differences in thoughts and experiences with local cultures, resulting in a hybrid curriculum [9]. Through the differences above, it can be understood that educators can create a hybrid curriculum to suit children's local needs. Learning programs developed by educators can be a solution in overcoming differences in local conditions with curricula made by the government.

\section{CONCLUSION}

The learning program is an important aspect in developing children's skills. Educators are required to think critically in seeing current knowledge and theories, because not all theories can be adapted to the needs of today's society. Through the basics and views of the experts above, I understand that educators must develop their knowledge in order to have a basis in critical thinking in seeing current theories. The theory that is the basis of education policy in Indonesia can be analysed by looking at the suitability of needs in today's society. One theory that is always used as a reference is the child-centred theory, whereas when viewed from the critical analysis of experts, this theory may not be in accordance with the conditions and needs of children. Adjustment of educational references to local needs can be done using a hybrid curriculum. In addition, educators must also train themselves to always see different perspectives in dealing with something. Training teachers to see the minority position is important so that justice can be felt by all parties. Through the views of experts, educators can reflect on becoming someone who is more critical in looking at a theory by looking at different sides to see suitability and fairness.

\section{REFERENCES}

[1] Rejeki NS, Suwardi S. Pengaruh kemampuan guru dalam mengelola kelas terhadap pembelajaran efektif di taman kanak-kanak. Jurnal Anak Usia Dini Holistik Integratif (AUDHI) [internet]. 2019;2(1):37-48. Available from https:// jurnal.uai.ac.id/index.php/AUDHI/article/view/579.

[2] Nisa K, Sujarwo. Efektivitas komunikasi guru terhadap motivasi belajar anak usia dini. Jurnal Obsesi: Jurnal Pendidikan Anak Usia Dini. 2020;5(1):229-40. Doi:10.31004/obsesi.v5i1.534.

[3] Setyosari P. Menciptakan pembelajaran yang efektif dan berkualitas. Jurnal Inovasi dan Teknologi Pembelajaran: Kajian dan riset dalam teknologi pembelajaran. 2017 Dec 13;1(1):20-30. Available from http://journal2.um.ac.id/index.php/jinotep/ article/view/2103/1239.

[4] Krieg S. To teach or not to teach in the early years: What does this mean in early childhood education. Early Childhood Education [internet]. 2018 [Cited March 13]:1-12. Available from: http://dx.doi.org/ 10.5772/ intechopen.80691.

[5] Gupta A. Early childhood education, postcolonial theory, and teaching practices in India: Balancing Vygotsky and the Veda. New York: Springer; 2006. 
[6] Burman E. Deconstructing developmental psychology. New York: Routledge; 2008.

[7] Alloway N. Early childhood education encounters the postmodern: What do we know? what can we count as 'true'?. Australian Journal of Early Childhood. 1997 Jun [Cited March 24];22(2):1-5. Available from: https://doi.org/10.1177\%2F183 693919702200202.

[8] MacNaughton G. Doing foucault in early childhood studies. New York: Routledge Taylor \& Francis Group; 2005. 18-19p.

[9] Jahng KE. Reconceptualizing kindergarten education in south korea: A postcolonial approach. Asia Pacific Journal of Education. 2013 March [Cited March 13];33(1):81-96. DOI: 10.1080/02188791.2012.751898.

[10] Mayo P. Gramsci and the politics of education. Capital \& Class. 2014;38(2):385-98. DOI: 10.1177/ 0309816814533170. 